
\title{
3 Research Square \\ Using the Winglet Toe and Twist Angle to Improve Wing Aerodynamics Performance
}

\section{Ali Jabbar Al-Khafaji ( $\nabla$ alhafadzhi@sfedu.ru )}

Southern Federal University: Uznyj federal'nyj universitet https://orcid.org/0000-0002-8595-270X

\section{Gennady S. Panatov}

SFedU Engineering and Technological Academy: Uznyj federal'nyj universitet Inzenerno-tehnologiceskaa akademia

\section{Anton S. Boldyrev}

SFedU Engineering and Technological Academy: Uznyj federal'nyj universitet Inzenerno-tehnologiceskaa akademia

\section{Research}

Keywords: lift, drag, lift and drag coefficient, aircraft wing, winglet, angle of attack, Toe and Twist angle, SOLIDWORKS, CFD, ANSYS FLUENT

Posted Date: July 7th, 2021

DOI: https://doi.org/10.21203/rs.3.rs-664368/v1

License: (c) (i) This work is licensed under a Creative Commons Attribution 4.0 International License. Read Full License 


\section{Abstract}

In this paper, we study the effect of winglet Toe \& Twist angle on the wing of the aircraft aerodynamics performances and how to improve it, we analyze the aerodynamics properties of the wing with winglets with Cant angle $60^{\circ}$ and winglet span $=3.5 \mathrm{~m}$, we test wings with different toe angles $\left(+10^{\circ},+5^{\circ}, 0^{\circ},-50\right.$, and $\left.-10^{\circ}\right)$ and twisted angles $\left(+5^{\circ}, 0^{\circ}\right.$, and $\left.+5^{\circ}\right)$ and all model are tested for four Angle of attack AOA $\left(0^{\circ}\right.$, $3^{\circ}, 6^{\circ}$, and $\left.9^{\circ}\right)$. Then calculate the value of $L / D$ to decide which wing has a high value of lift and lower drag. All models of a wing (sixty models) are drawn for 3D using the SOLIDWORKS program where we used Boeing 737-800 wing dimensions. Then all models of a wing were analyzed using ANSYS FLUENT.

\section{Introduction}

The pressure differential at the top and bottom of wing produces lift, By the lift presence, the vortices produced at the wing tips are inevitable items, so it implies the difficulties induced by force supporting the aircraft in the air. The presence of Induced Drag is caused by these vortices. The size of this vortex is known to be very risky for air traffic in the case of civil aviation, and its dissipation is calculated to be two minutes on average. This period of time is called an interval of two landings or two takeoffs. This vortex is also seen as a critical element in airport architecture.[1] [2] and we know the aerospace industry depends on the continual advancement of current technology and the innovative production of new designs to increase the return on investment in the construction of aircraft.[3] Aircraft designer as a way of minimizing the induced wing drag, winglets have been used on aircraft.[4]

Winglets are small wing extensions that are pointed upward or backward at the tip of the wing. Like the wingtip feathers of birds in flight, they can also bend effortlessly.[5] During winglet design, a variety of winglet design parameters such as span, sweep, cant, toe, twist and aspect ratio should be taken into account.[6] In this project we will study the effect of two parameter, Toe and Twist angle.

The Toe angle changes the winglet's direction at the point of attachment to the wing. This change in angle causes a change in the winglet incidence angle, resulting in a change in the distribution of the lift that can increase the lift, but at the same time drag variations. The key use of the angle of the toe is as a load reducing mechanism that will overcome the rising loads due to the winglet installation (This is mainly valid for retrofitted winglets). The winglet's Twist angle is used to mitigate the negative effects of the toe angle modification. With the twist angle adjustment, the $L / D$ values that are influenced by the differences of the toe angle can be raised without influencing the Wing loads in a significant way. [7]

\section{Wing Models Description}

SOLIDWORKS software program is using in this project, to build sixty 3D models and then analyzing using ANSYS (Fluent) software program, we using different Toe angles $\left(+10^{\circ},+5^{\circ}, 0^{\circ},-5^{\circ}\right.$, and $\left.-10^{\circ}\right)$ and Twist angles $\left(+5^{\circ}, 0^{\circ}\right.$, and $\left.-5^{\circ}\right)$ to build models, with fixed Cant angle $60^{\circ}$, winglet span $3.5 \mathrm{~m}$, and 
winglet tip $375 \mathrm{~mm}$, see Figures (1)(2)(3)(4)). All model builds with four Angle of attack AOA $\left(0^{\circ}, 3^{\circ}, 6^{\circ}\right.$, and $9^{\circ}$ ) with wing dimensions as follow see Figure (5): -

1. Mean Aerodynamic Chord (basic wing only) 13 feet and 0 inch (3.96 M)

2. Planform Taper Ratio - Tip Chord (Root Chord) -0.219

3. Root Chord (theoretical, at Body Centerline) - 18 feet and 9 inches (5.71 M)

4. Sweepback (at the 25 percent chord line) -25.03 degrees

5. Tip Chord (theoretical) -4 feet and 1.25 inches (1.25 M)

We assume that the model: - Space 3D Time Steady Viscous SST k-omega. Velocity Magnitude $(\mathrm{m} / \mathrm{s})$ 230 wing Condition. Reference value: - Boeing 737-800, typical cruising altitude 35,000 ft. with cruising speed 0.78 Mach. [8], temperature - $51\left(\mathrm{C}^{\circ}\right)$ [9], density: $1.5915\left(\mathrm{~kg} / \mathrm{m}^{\wedge} 3\right)$, dynamic viscosity: $1.4584 \mathrm{E}-5$ $(\mathrm{kg} / \mathrm{m} . \mathrm{s})[10]$, pressure: 3.46 (pascal).[11]

\section{Results}

CFD simulations (ANSYS FLUENT) have been done for the sixty wing models with different winglet and then comparing the aerodynamics characteristics of lift coefficient $C_{L}$, drag coefficient $C_{D}$, and lift-to-drag ratio (L/D). We calculate the value of lift and drag force, see Figure $(6,7)$ for all wing models, and specify the max. and min value of lift and drag see Table $(1,2)$, we can see both values of lift \& drag values increasing with the increasing the values of angle of attack it gives us an indication for the behavior of the lift and drag force of all wing model but not obvious, we calculate L/D see Figure (8) for all model and we specify the maximum value L/D at AOA, see Table (3), In Figure (9) we can see the wing ANSYS FLUENT analysis for two models they represent the maximum and minimum L/D value and see the vortex generation on every wing, so for our model dimension, the reference value, and our select winglet type we get this value, which can differ when we change any element.

\section{Conclusion}

Winglets in general invented to enhance the aerodynamic properties by decrease the induced drag generation in the tip of the wing and there are different ways for optimization.

In this paper, we change the winglet Toe and Twist angle in a way that increases the lift force with decreases the drag force. it's important to find the optimal combinations between these two angles taken into consideration the dimensions and assumptions of our wing.

In our model, we assume Toe angles $\left(+10^{\circ},+5^{\circ}, 0^{\circ},-5^{\circ}\right.$, and $\left.-10^{\circ}\right)$ and twisted angles $(+50,00$, and +50$)$ versus four angles of attack $(00,30,60$, and 90$)$ after calculation we get that, the best result from the sixty models is when the Toe angle is -5 and Twist angle is +5 at an angle of attack 3 according to our wing data. 
The results can be improved by testing the wing with more specified values depending on our result such as Toe angle $\left(-6^{\circ},-5^{\circ}\right.$, and $\left.-4^{\circ}\right)$, Twist angle $\left(+6^{\circ},+5^{\circ}\right.$, and $\left.+4^{\circ}\right)$ versus angle of attack $\left(+2^{\circ},+3^{\circ}\right.$, and + $\left.4^{\circ}\right)$.

\section{Declarations}

\section{Availability of data and materials}

Wing dimension data is taken from the real airplane wing of Boeing 737-800. Analysis of the wing done in the condition of cruise flight phase due to the airplane flies at a more or less constant altitude and this is generally the longest phase of the flight.

\section{COMPETING INTERESTS}

The authors declare that they have no known competing financial interests or personal relationships that could have appeared to influence the work reported in this paper.

\section{FUNDING}

Southern Federal University / The Institute of Radio Engineering Systems and Control.

\section{AUTHOR'S CONTRIBUTION}

Conceptualization, Gennady S. Panatov, Anton S. Boldyrev; Ali J. Dawood Al-Khafaji; Methodology, Gennady S. Panatov, Anton S. Boldyrev. Investigation and Writing - Original Draft, Ali J. Dawood AlKhafaji; Writing - Review and Editing, Gennady S. Panatov, Anton S. Boldyrev; Resources, Ali J. Dawood Al-Khafaji; Supervision, Gennady S. Panatov, Anton S. Boldyrev.

\section{ACKNOWLEDGMENTS}

Authors are thankful to Advances in Aerodynamics (AIA) for support for publishing this article, and also to all the reviewers for providing very constructive feedback to this paper.

\section{References}

1 Belferhat, S., Meftah, S., Yahiaoui, T., and Imine, B.: 'Aerodynamic Optimization of a Winglet Design', in Editor (Ed.)^(Eds.): 'Book Aerodynamic Optimization of a Winglet Design' (EDP Sciences, 2013, edn.), pp. 
01010

2 Srikanth, G., and Surendra, B.: 'Experimental investigation on the effect of multi-winglets', International Journal of Mechanical \& Industrial Engineering, 2011, 1, (1), pp. 43-46

3 Lappas, I., and Ikenaga, A.: 'Conceptual design and performance optimization of a tip device for a regional turboprop aircraft', Aerospace, 2019, 6, (10), pp. 107

4 Pfeiffer, N.: 'Numerical winglet optimization', in Editor (Ed.)^(Eds.): 'Book Numerical winglet optimization' (2004, edn.), pp. 213

5 Guerrero, J., Sanguineti, M., and Wittkowski, K.: 'CFD study of the impact of variable cant angle winglets on total drag reduction', Aerospace, 2018, 5, (4), pp. 126

6 Paudel, P.: 'Aerodynamic aspects in the development of morphing winglet for a regional aircraft', Dept. App. Sci. Aerospace. Eng. Ryerson University, 2013

7 Cancino Queirolo, M.A.: 'Impact of Morphing Winglets on Aircraft Performance', 2018

8 https://www.rocketroute.com/aircraft/boeing-737-800

9 https://www.livescience.com/

10 http://www.mhtl.uwaterloo.ca/properties.html

11 https://www.engineeringtoolbox.com/air-altitude-pressure-d_462.html

\section{Tables}

Table (1) Lift force value

\begin{tabular}{|lll|}
\hline Function & Value & Description \\
\hline Max. lift & 1150965.9 & Toe Angle $+5^{\circ}$ \\
& & Twist Angle $+5^{\circ}$ \\
& & Angle of attack 9 \\
Min. lift & 99360.469 & $\begin{array}{l}\text { Toe Angle }-10^{\circ} \\
\text { Twist Angle }-5^{\circ}\end{array}$ \\
& & Angle of attack $0^{\circ}$ \\
\hline
\end{tabular}




\begin{tabular}{|lll|}
\hline Function & Value & Description \\
\hline Max. drag & 189117.98 & $\begin{array}{l}\text { Toe Angle }+10^{\circ} \\
\text { Twist Angle } 0^{\circ} \\
\end{array}$ \\
& & Angle of attack $0^{\circ}$ \\
\hline Min. drag & 12843.399 & $\begin{array}{l}\text { Toe Angle } 0^{\circ} \\
\text { Twist Angle }-5^{\circ}\end{array}$ \\
& & Angle of attack $0^{\circ}$ \\
\hline
\end{tabular}

Table (3) Lift to drag ratio value

\begin{tabular}{|lll|}
\hline Function & Value & Description \\
\hline Max. L/D & 18.67 & Toe Angle $-5^{\circ}$ \\
& & Twist Angle $+5^{\circ}$ \\
& & Angle of attack $3^{\circ}$ \\
Min. L/D & 5.23 & Toe Angle $-10^{\circ}$ \\
& & Twist Angle $0^{\circ}$ \\
& & Angle of attack $0^{\circ}$ \\
\end{tabular}

Figures 

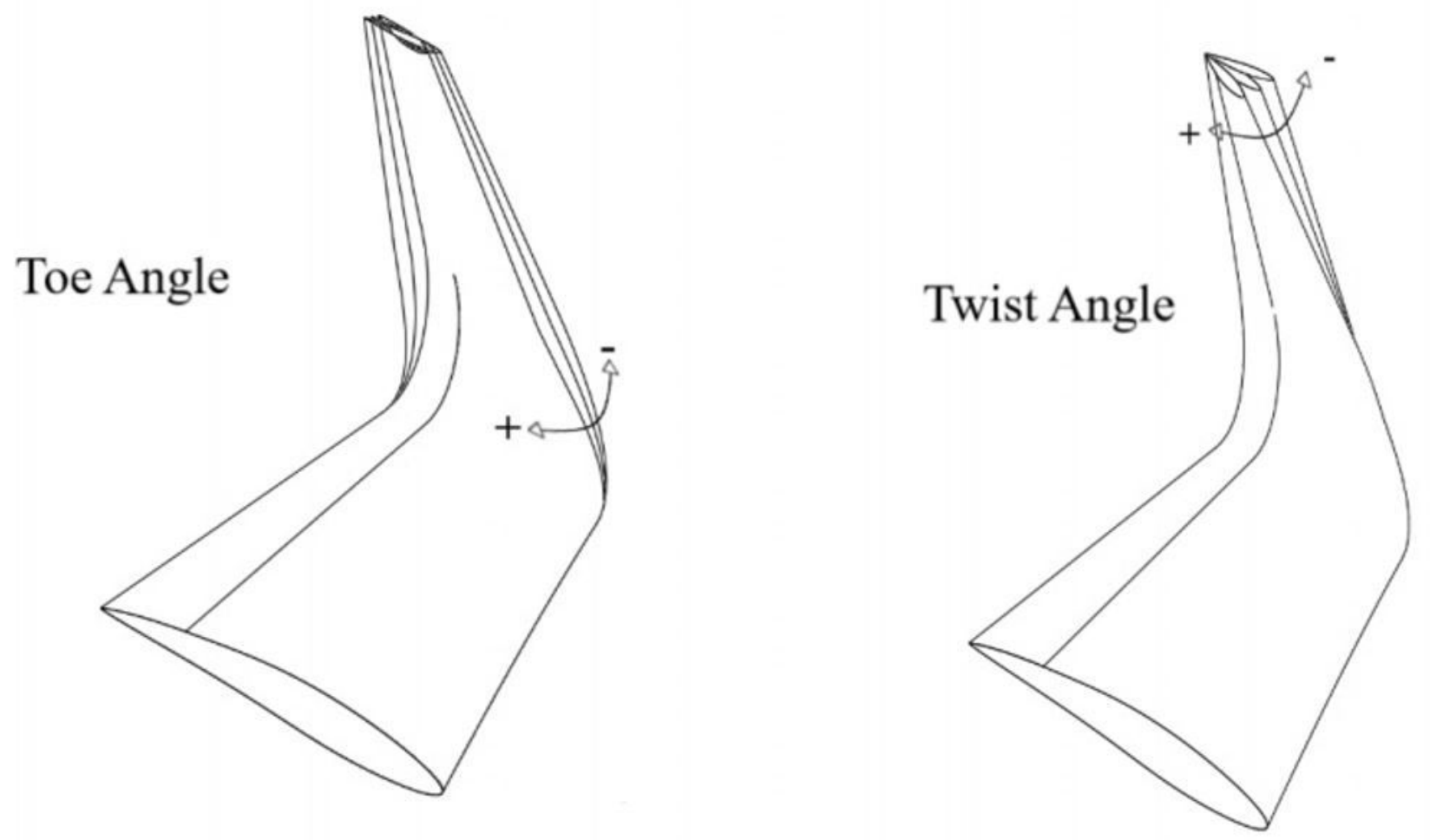

Figure 1

Winglet Toe and Twist Angle 


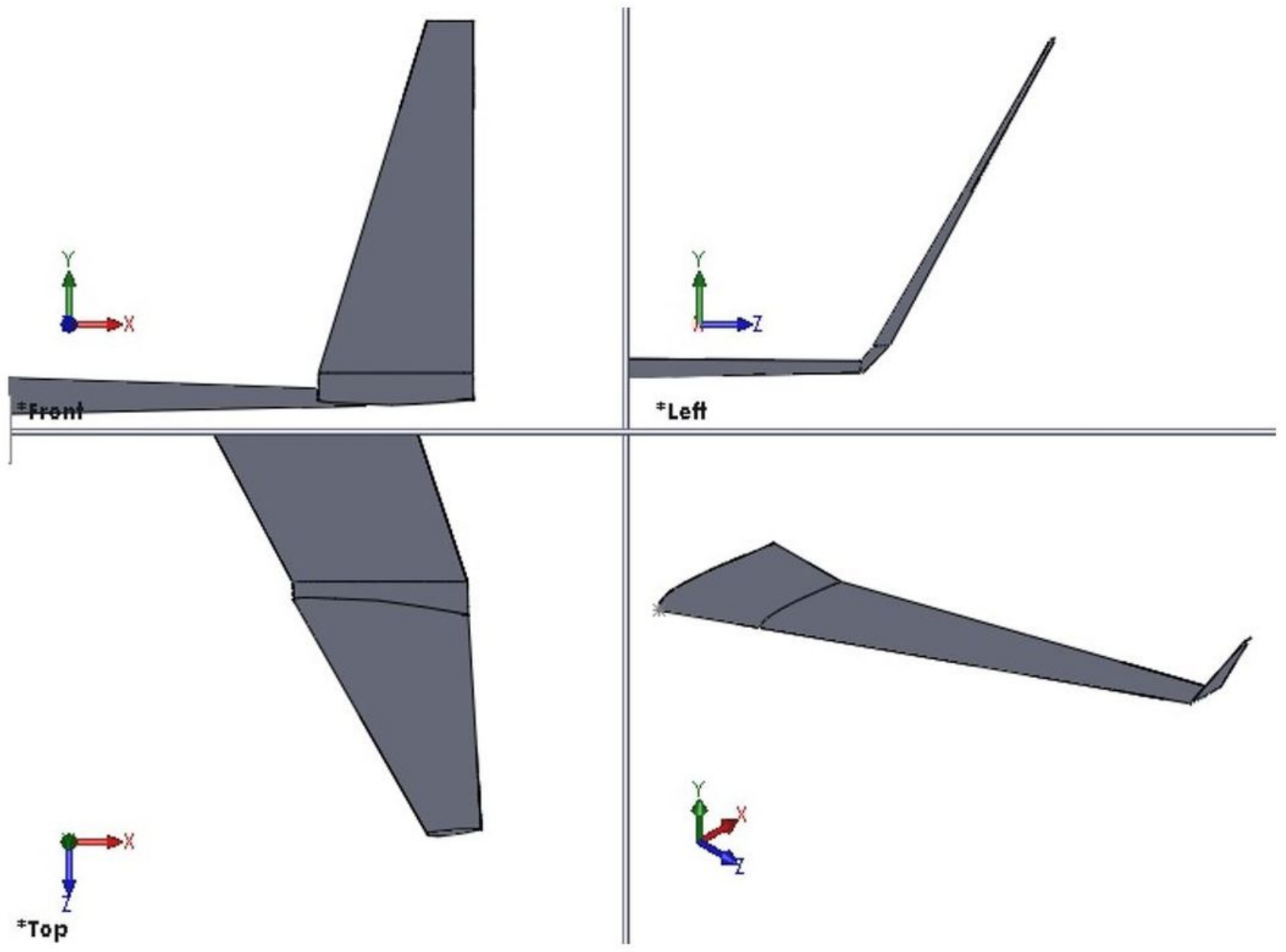

Figure 2

Wing shape with a different view orientation 


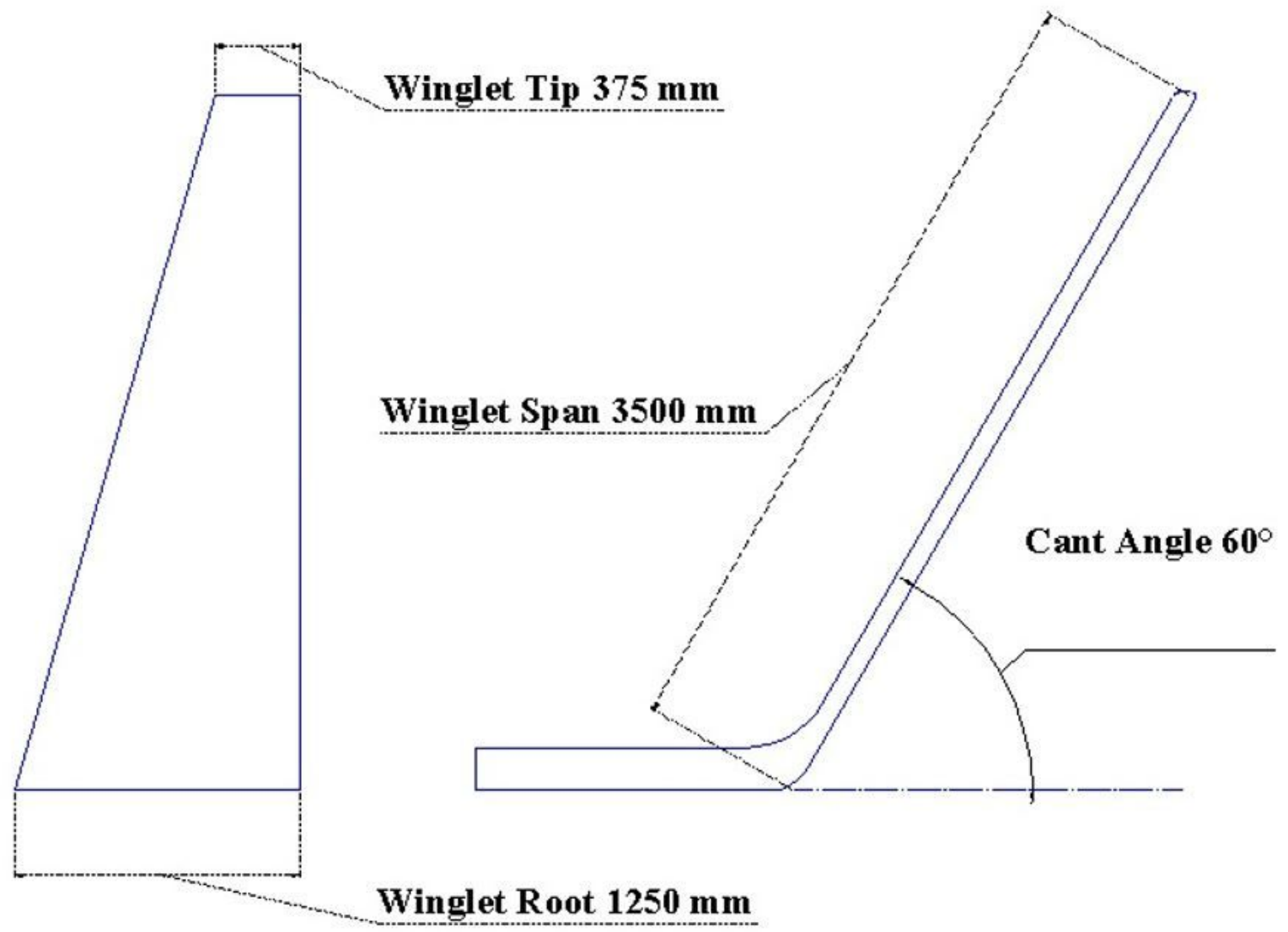

Figure 3

Winglet Dimension
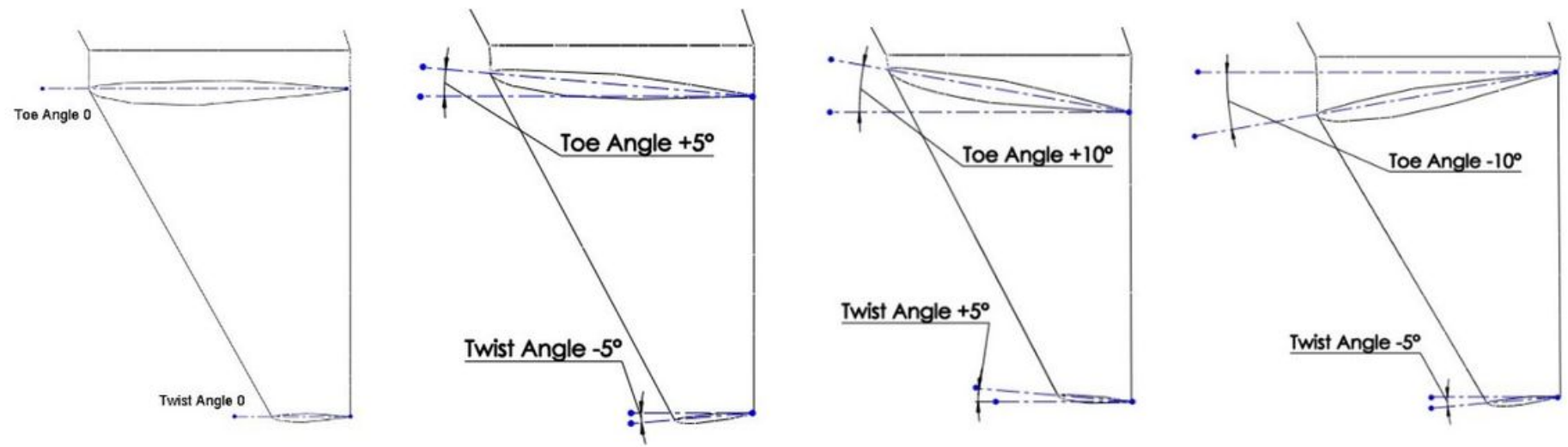

Figure 4

Wing shape with a different Winglet Toe \& Twist angle 

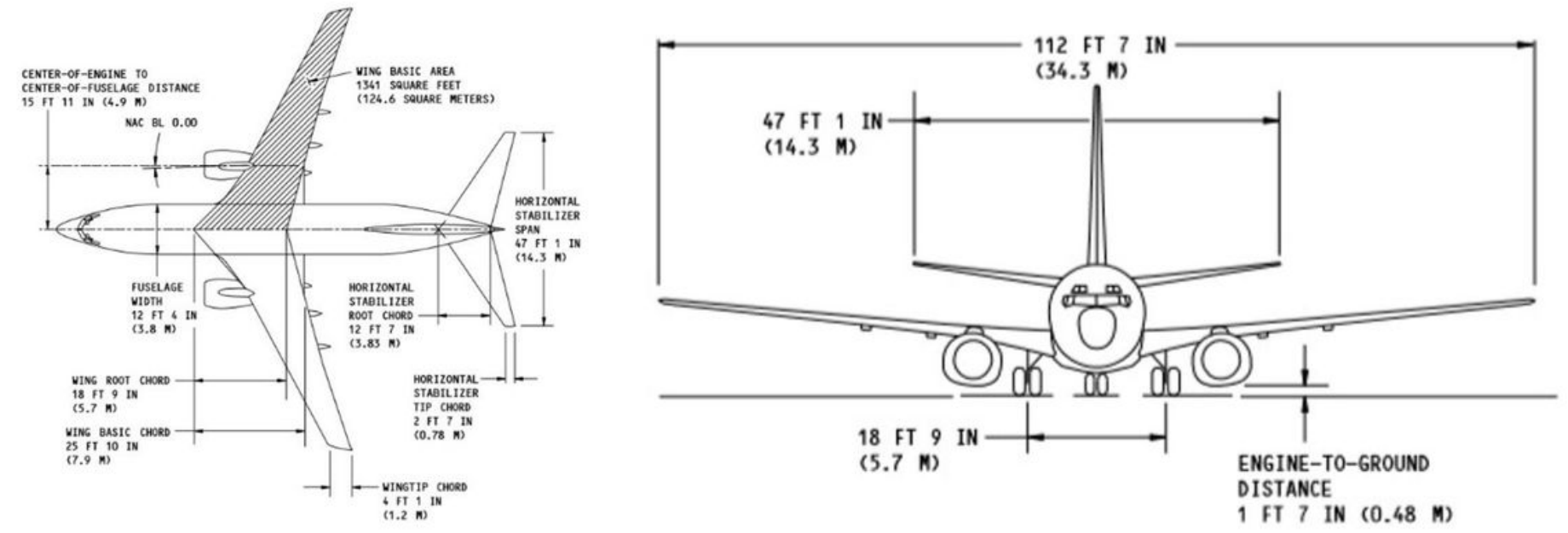

Figure 5

Wing dimensions

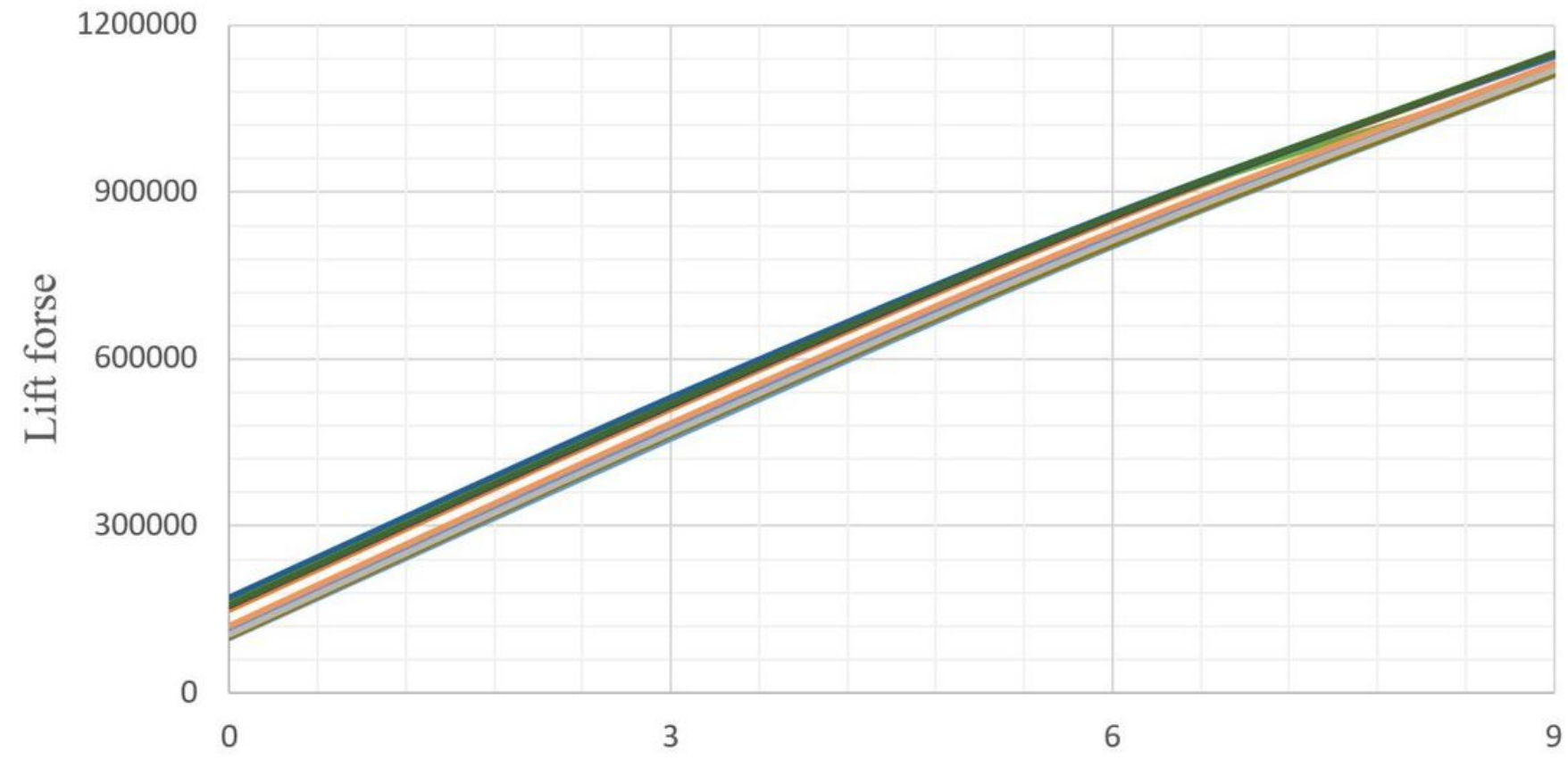

Angle of attack

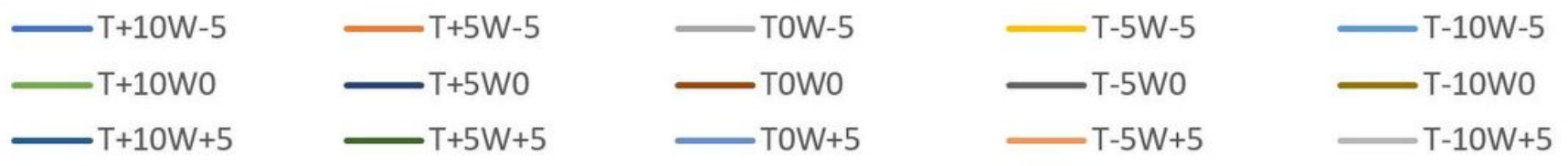

Figure 6

Lift force of a wing with different winglet Toe angle $T(+100,+50,00,-50$, and -100$)$ and Twist angle W $(+50,00$, and +50$)$ versus different angle of attack $(00,30,60$, and 90$)$ 


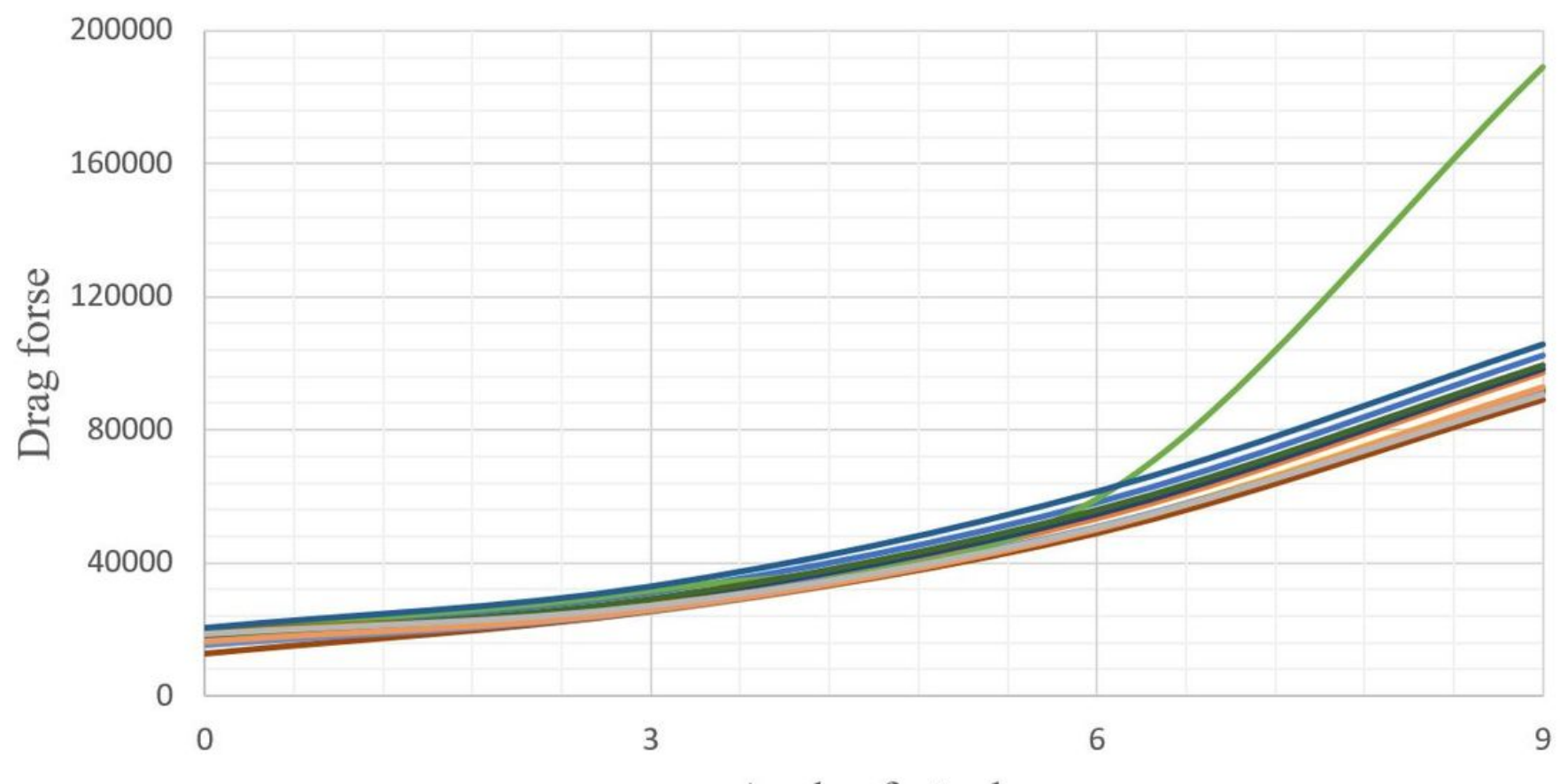

Angle of attack

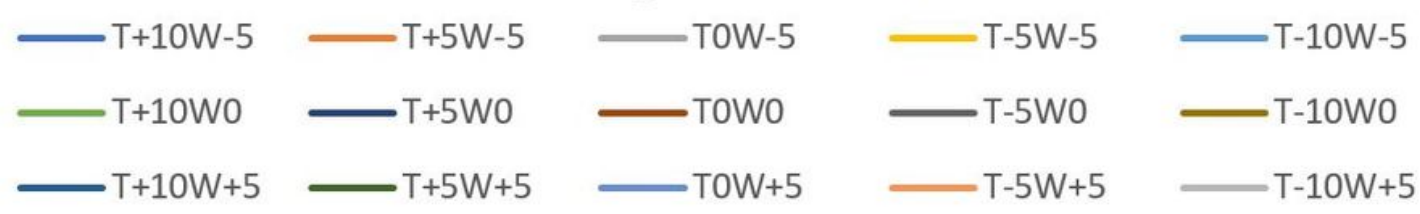

\section{Figure 7}

Lift force of a wing with different winglet Toe angle $\mathrm{T}(+10 \mathrm{o},+50,00,-50$, and $-10 \mathrm{o})$ and Twist angle W $(+50,00$, and +50$)$ versus different angle of attack $(00,30,60$, and 90$)$ 


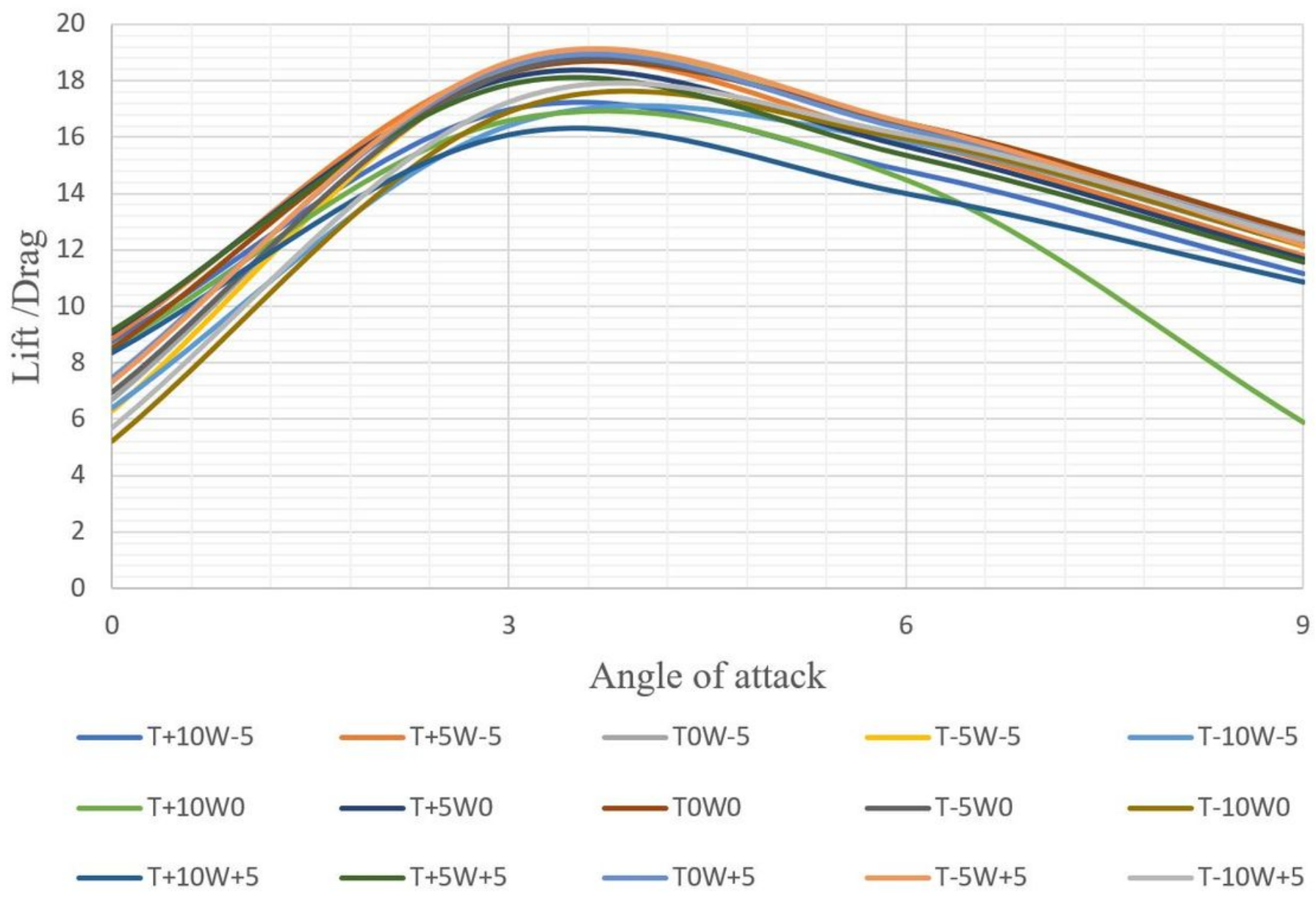

Figure 8

Lift to drag force L/D of a wing with different winglet Toe angle T $(+100,+50,00,-50$, and -100$)$ and Twist angle $\mathrm{W}(+50,00$, and +50$)$ versus different angle of attack $(00,30,60$, and 90$)$ 

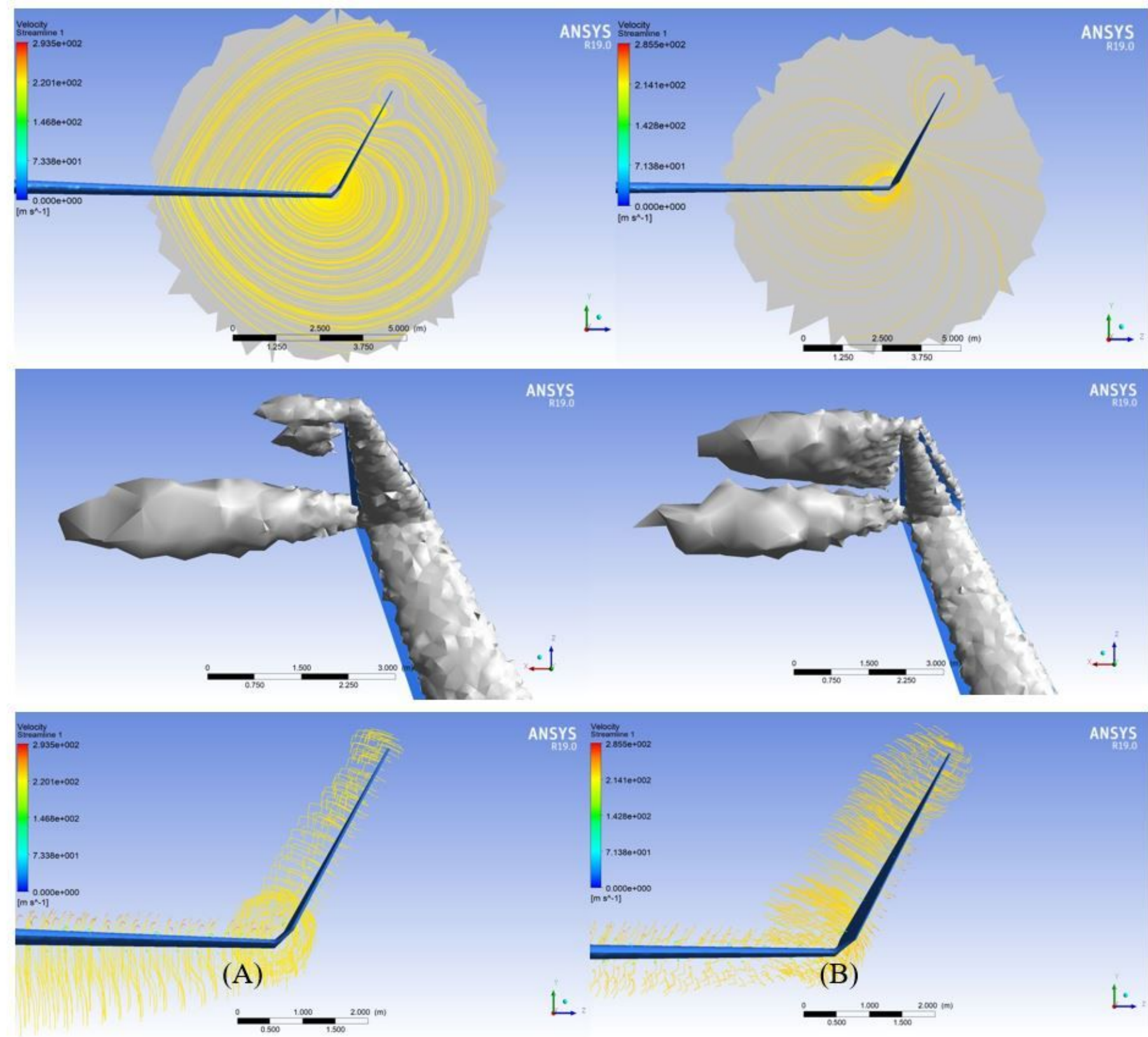

\section{Figure 9}

Wing ANSYS FLUENT analysis for model (A) winglet with Toe angle -50 , Twist angle +50 , and angle of attack +30 , (B) winglet with Toe angle -100 , Twist angle 0 o, and angle of attack $0 \mathrm{o}$ 